\title{
PENGEMBANGAN FILM PEMBELAJARAN ILMU PENGETAHUAN ALAM UNTUK SEKOLAH DASAR (Studi Kasus : Kelas 5 SD No. 7 Benoa)
}

\author{
Ni Made Ria Hartini'1), Gede Saindra Santyadiputra²), Gede Aditra Pradnyana ${ }^{3)}$ \\ ${ }^{1}$ Fakultas Teknik dan Kejuruan, Universitas Pendidikan Ganesha \\ e-mail : ria.hartini14@gmail.com \\ ${ }^{2}$ Fakultas Teknik dan Kejuruan, Universitas Pendidikan Ganesha \\ e-mail : gsaindras@undiksha.ac.id \\ ${ }^{3}$ Fakultas Teknik dan Kejuruan, Universitas Pendidikan Ganesha \\ e-mail : gede.aditra@undiksha.ac.id
}

\begin{abstract}
Abstrak
Penelitian ini bertujuan untuk (1) menghasilkan rancangan dan mengimplementasikan film pembelajaran ilmu pengetahuan alam untuk kelas 5 SD No. 7 Benoa ; (2) mengetahui respon guru dan siswa kelas 5 terhadap film pembelajaran IImu Pengetahuan Alam (IPA) untuk Kelas 5 Sekolah Dasar No.7 Benoa. Jenis penelitian yang digunakan dalam penelitian ini adalah Penelitian dan Pengembangan $(R \& D)$ dengan model $A D D I E$. Penelitian ini melibatkan siswa Kelas 5 Sekolah Dasar No. 7 Benoa. Teknik pengumpulan data yaitu dengan cara wawancara, angket, dan dokumentasi. Hasil penelitian dan pengembangan menunjukkan bahwa ilmu pengetahuan alam dalam kriteria sangat baik. Hasil yang diperoleh berdasarkan analisis uji ahli isi, uji ahli desain, dan uji ahli media. Berdasarkan pengujian pada tahap implementasi yaitu uji individu, uji kelompok kecil dan uji lapangan yang dibagi menjadi 2 tahapan yaitu tahap pretest dan posttest menunjukan bahwa hasil yang dapatkan siswa sudah diatas KKM. Respon guru menyatakan film pembelajaran ilmu pengetahuan alam masuk dalam kreteria sangat baik. Sedangkan rata-rata respon siswa menyatakan film pembelajaran IPA Kelas 5 masuk dalam kriteria sangat baik. Berdasarkan analisis dari 41 siswa diketahui 31 siswa menyatakan film pembelajaran ilmu pengetahuan alam masuk dalam kriteria sangat baik dan 10 siswa menyatakan film pembelajaran ilmu pengetahuan alam masuk dalam kriteria baik. Kesimpulan yang didapat yaitu sudah berhasil mengembangkan Film Pembelajaran IImu Pengetahuan Alam Kelas 5 Sekolah Dasar No. 7 Benoa dan sudah berhasil mendeskripsikan respon guru dan siswa terhadap pengembangan Film Pembelajaran IImu Pengetahuan Alam Kelas 5 Sekolah Dasar No. 7 Benoa.
\end{abstract}

Kata kunci: Film pembelajaran, ilmu pengetahuan alam, sekolah dasar

\begin{abstract}
Research aims to (1) generate a design and implement learning movies nature of science for grade 5 Elementary School No. 7 Benoa; (2) know the response of teachers and students of class 5 against learning natural science films (IPA) to grade 5 primary school No.7 Benoa. The type of research used in this research is the research and development (R\&D) and ADDIE model. This research involves the grade 5 elementary school No. 7 Benoa. The technique of data collection that is by way of interviews, question form, and documentation. The results of the research and development shows that the science of nature in the criteria very well. The results obtained on the basis of the analysis of the expert test content, test design, and test expert media expert. Based on testing at this stage of the implementation of the test i.e. the individual, small group test and field test which is divided into 2 phases i.e. phase pretetst and posttest results indicate that students already get above KKM. The teacher's response stated the film learning natural science entry in kreteria is very good. While the average student response stated the film learning the IPA class 5 entered in the criteria very well. Based on the analysis of 41 students known to 31 students stated learning natural science films entered in the criteria very well and 10 students stated learning natural science films entered in the criteria either. Conclusions that is already successfully developed the Film Learning natural science grade 5 primary school No.7 Benoa and already managed to describe the response of teachers and students towards the development of the Film Learning natural science grade 5 primary school No.7 Benoa.
\end{abstract}

Keywords: Film study, natural sciences, primary school 


\section{PENDAHULUAN}

Media film dalam pembelajaran dapat membantu menjelaskan hal-hal yang abstrak dan memberikan gambaran yang lebih realistik. Salah satu contoh pembelajaran yang membutuhkan gambaran realistik adalah ilmu pengetahuan alam (IPA). IPA berfungsi untuk memberikan pengetahuan tentang lingkungan alam, mengembangkan keterampilan, wawasan, dan kesadaran teknologi dalam kaitan dengan pemanfaatannya bagi kehidupan sehari-hari. Sains mempunyai makna merujuk ke pengetahuan yang berada dalam sistem berpikir dan konsep teoritis dalam sistem tersebut, yang mencakup segala macam pengetahuan, mengenai apa saja [1]. Materi yang terkandung dalam tiap pembelajaran sudah lebih spesifik namun dalam proses pembelajarannya masih membutuhkan metode dan media pembelajaran yang inovatif dan efektif sebagai alternatif apabila kondisi pembelajaran kurang sesuai dengan pembelajaran. Mengingat pentingnya IPA tersebut, sebuah inovasi pembelajaran diperlukan untuk mempermudah peserta didik dalam belajar IPA.

Berdasarkan hasil wawancara pada hari Rabu, tanggal 20 Januari 2016 dengan Guru Mata Pelajaran IPA Kelas 5 yakni lbu Ni Putu Suartini, S.Pd.SD, bahwa SD No. 7 Benoa merupakan salah satu sekolah dasar yang belum memiliki media pembelajaran IPA yang memadai, sehingga masih menggunakan metode ceramah, diskusi, dan menggunakan alat peraga untuk menjelaskan materi pembelajaran yang ada. Menurut pengamatan guru mata pelajaran IPA, ada beberapa siswa yang senang belajar IPA namun ada juga yang kurang tertarik bahkan menganggap pelajaran IPA membosankan. Ini terlihat dari persentase ketuntasan kelas 5 dalam pelajaran IPA adalah sebanyak $55 \%$ siswa dari total siswa sudah tuntas.

Menurut lbu Ni Putu Suartini, S.Pd.SD, kendala yang dihadapi selama proses pembelajaran di kelas 5 yaitu dalam menyajikan beberapa materi masih belum maksimal karena kekurangan media pembelajaran dan alat peraga sehingga siswa masih belum bisa memahami materi dengan baik.

Hasil penyebaran angket yang dilaksanakan pada hari Rabu, tanggal 20 Januari 2016 terhadap siswa kelas 5 di SD No.7 Benoa menunjukan sebanyak 50,82 \% siswa mengatakan menyukai pelajaran IPA dan $49,18 \%$ mengatakan menyukai pelajaran lain. Hasil lainnya menunjukan bahwa 81,97 \% siswa menyatakan kurang tertarik dengan materi IPA yang dijelaskan oleh guru dan $59,02 \%$ siswa menyatakan pelajaran IPA mudah untuk dimengerti, namun ada juga siswa yang beranggapan IPA adalah mata pelajaran yang sulit sehingga 40,98 \% siswa menyatakan mengalami kesulitan dalam belajar IPA. Dari penyebaran angket juga didapatkan hasil bahwa beberapa siswa belum mengenal media pembelajaran dalam bentuk elektronik karena dalam pelajaran di kelas yang dilakukan selama ini masih menggunakan media berupa gambar dan alat peraga karena itu 31,15\% siswa menyatakan media pembelajaran membuat kesulitan dalam belajar. Berbeda halnya dengan siswa yang sudah mengetahui bentuk media pembelajaran yang justru lebih menyukai pembelajaran menggunakan media, hal ini terlihat dari hasil penyebaran angket yaitu sebanyak $68,85 \%$ menyatakan lebih suka belajar mengunakan media pembelajaran dalam belajar IPA. Karena itu diperlukan inovasi dalam penggunaan media pembelajaran agar lebih menarik minat siswa dalam belajar dikelas, dalam hal ini alternatif yang dipilih adalah film pembelajaran dimana 52,46 \% siswa menyatakan tertarik jika media pembelajaran disajikan dalam bentuk film. Namun beberapa siswa belum mengenal film pembelajaran, sehingga $47,54 \%$ menyatakan tidak mengerti dengan media pembelajaran yang disajikan dalam bentuk film.

Berdasarkan analisis kebutuhan yang telah dipaparkan, salah satu jawaban alternatif dari masalah yang ada adalah pemanfaatan film sebagai media pembelajaran. Media film memiliki beberapa manfaat dalam meningkatkan efektivitas dan efisiensi proses pembelajaran yaitu film pembelajaran dapat memperjelas hal-hal yang abstrak dan memberikan gambaran yang lebik realistik, film pembelajaran juga sangat baik menjelaskan suatu proses dan dapat menjelaskan suatu keterampilan [6]. Menurut ibu Ni Putu Suartini,S.Pd.SD selaku pengajar IPA di SD No. 7 Benoa, pengaruh film pembelajaran sangat besar dalam proses pembelajaran karena melalui film pembelajaran siswa akan lebih mudah memahami materi dan lebih mudah untuk mengingat materi yang telah diajarkan.

Efektivitas penggunaan Media Film Dokumenter Alam Semesta pada Pembelajaran IPA Materi Tata Surya Terhadap Hasil Belajar Siswa Kelas IX SMP Walisongo 1 Semarang dimana hasil penelitian menunjukan bahwa penggunaan media film dokumenter alam semesta pada pembelajaran IPA materi tata surya lebih efektif dibandingkan 
pembelajaran konvensional tanpa menggunakan media [5]. Sedangkan Film pembelajaran Pendidikan Kewarganegaraan untuk membentuk karakter Pebelajar Kelas III Sekolah Dasar menunjukkan peningkatan kinerja siswa dengan penilaian tuntas [9]. Penelitian lain juga mengembangkan film dokumenter sebagai pendukung pembelajaran Akuntasi pokok bahasan siklus akuntansi perusahaan dagang. Hasil pengembangan film ini menunjukan bahwa media film dokumenter yang dikembangkan menurut ahli materi, ahli media pembelajaran dan siswa, sangat layak serta bisa digunakan untuk mendukung pembelajaran Akuntansi [4]. Pengembangkan Film Pembelajaran Musim Penghujan pada Tema Peristiwa Alam untuk Siswa Kelas I Sekolah Dasar Laboratorium Undiksha Singaraja dengan hasil penelitian menunjukkan bahwa respon siswa terhadap film pembelajaran musim penghujan dalam kriteria sangat baik. Sesuai dengan penelitian tersebut maka film pembelajaran sangat efektif dan layak digunakan sebagai media pendukung pembelajaran untuk meningkatkaan kinerja siswa dengan penilaian tuntas [13]. Penelitian ini sejalan dengan penilitian mengenai pengembangkan Film Pembelajaran Sosiologi pada Kompetensi Mendiskripsikan Nilai dan Norma yang Berlaku dalam Masyarakat untuk Siswa Kelas $X$ di SMA Negeri 2 Singaraja dengan hasil penilitian yang masuk dalam kriteria sangat baik. [12]

\section{METODE}

Pengembangan Film Pembelajaran IImu Pengetahuan Alam Untuk Kelas 5 Sekolah Dasar No. 7 Benoa menggunakan jenis penelitian dan pengembangan (Research and Development). Desain pengembangan dalam penelitian ini menggunakan model Analysis Design Development Implementation Evaluation (ADDIE).

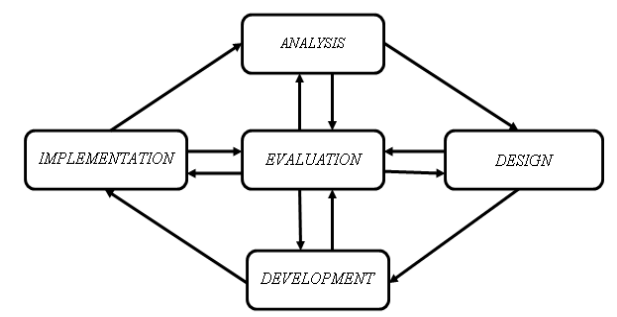

Gambar 1. Model Analysis Design Development Implementation Evaluation (ADDIE) [14]

\section{Langkah-langkah Penerapan Model ADDIE}

\section{a. Analisis}

Pada tahap ini dilakukan analisis kebutuhan, baik berupa kebutuhan fungsional maupun kebutuhan non fungsional. Pada tahap analisis, peneliti melakukan wawancara dengan guru bidang studi IPA di SD No. 7 Benoa untuk mengetahui penggunaan media pembelajaran dalam bentuk film di SD No. 7 Benoa dalam proses pembelajaran. Selain itu juga dilakukan penyebaran angket untuk siswa kelas 5 dengan tujuan untuk mengatahui pengetahuan siswa tentang film pembelajaran. Dalam tahap ini juga dilakukan beberapa analisis yang untuk mendukung pembuatan film pembelajaran. Adapun analisis tersebut adalah : (1) Analisis Kurikulum. (2) Analisis Silabus dan RPP. (3) Analisis Sumber Belajar / Materi. (4) Analisis Karakteristik Siswa. (5) Analisis Kebutuhan Film

\section{b. Desain}

Pada tahap desain, penulis mendesain cerita film untuk setiap kegiatan pembelajaran berdasarkan indikator pembelajaran. Jumlah indikator pembelajaran pada mata pelajaran IPA semester 1 yaitu 30 indikator. Dari 30 indikator pembelajaran tersebut guru dan penulis memilih 16 indikator pembelajaran yang dinilai membutuhkan media dalam kegiatan pembelajarannya dan kemudian menyusun indikator pembelajaran tersebut secara sistematis agar menghasilkan ide cerita yang menarik. Film pembelajaran ini terdiri atas tiga seri film. Seri pertama berjudul Organ Tubuh Manusia dan Hewan terdiri dari tiga episode yaitu episode Alat Pernapasan Manusia dan Hewan, Alat Pencernaan Manusia, dan Alat Peredaran Darah Manusia, seri kedua berjudul Tumbuhan Hijau yang terdiri dari satu episode yang berjudul Fotosintesis Tumbuhan Hijau dan seri ketiga berjudul Penyesuaian Diri Hewan dan Tumbuhan terhadap Lingkungan yang terdiri dari 1 episode yang berjudul Adaptasi Hewan dan Tumbuhan. Durasi untuk setiap episode yaitu 15 sampai 20 menit dan materi pembelajaran disampaikan di setiap adegan film, baik melalui audio maupun visual/grafis. Film pembelajaran IPA ini menggunakan tombol menu agar lebih memudahkan pengguna dalam memilih materi yang digunakan. Ada tiga tombol menu yaitu tombol untuk organ tubuh manusia, tumbuhan hijau dan penyesuaian diri hewan dan tumbuhan terhadap lingkungannya. Menu Organ tubuh manusia terdapat tiga submenu yaitu Alat Pernapasan Manusia dan Hewan, Alat 
Pencernaan, dan Peredaran Darah. Menu Tumbuhan Hijau terdapat satu submenu yaitu Fotosintesis Tumbuhan Hijau. Menu Penyesuaian Diri Hewan dan Tumbuhan terhadap Lingkungannya terdapat satu submenu yaitu Adaptasi Hewan dan Tumbuhan. Tahap desain ini juga merupakan tahap pra produksi dari tahap-tahap pembuatan film pembelajaran.

\section{c. Pengembangan}

Pengembangan merupakan langkah ketiga dalam mengimplementasikan model desain sistem pembelajaran ADDIE. Pada tahap ini desain film yang berupa sinopsis, storyline, dan storyboard akan dikembangkan. Dengan kata lain proses pembuatan film akan dilakukan pada tahap ini. Tahap pengembangan berada pada tahap produksi dan pasca produksi dalam tahapan-tahapan pembuatan film pembelajaran. Dalam tahapan pengembangan dilakukan beberapa hal, antara lain: (1) Pengambilan Gambar. (2) Audio Productio. (3) Pembuatan Animasi 2 Dimensi (4) Editing Film.

\section{d. Implementasi}

Pada tahap implementasi ini dilakukan penggandaan / memproduksi film yang telah dikembangkan dalam bentuk DVD, kemudian melakukan pelatihan penggunaan film kepada ibu Ni Putu Suartini, S.Pd.SD., dan yang terakhir yaitu melakukan uji implementasi terhadap film pembelajaran.

\section{e. Evaluasi}

Dalam penelitian ini, evaluasi formatif terus dilakukan di setiap tahap pengembangan. Adapun evaluasi formatif yang dilakukan, diantaranya:

1. Evaluasi pada Tahap Analisis

Evaluasi pada tahap analisis dilakukan dengan cara pengisian instrument evaluasi oleh ahli isi. Uji ahli isi dilakukan untuk mengetahui kesesuaian isi film Pembelajaran IPA Kelas 5 SD dengan silabus dan materi pelajaran.

2. Evaluasi pada Tahap Desain

Evaluasi pada tahap desain dilakukan dengan cara pengisian instrumen evaluasi desain oleh uji ahli desian. Adapun aspek yang dievaluasi dalam tahap desain adalah kesesuaian tujuan pembelajaran, efektifitas film pembelajaran, dan kesesuaian evaluasi.

3. Evaluasi pada Tahap Pengembangan

Evaluasi pada tahap development dilakukan dengan cara pengisian instrumen evaluasi development oleh ahli media. Uji ahli media dilakukan untuk mengetahui apakah film yang dikembangkan siap untuk dipublikasikan atau tidak.

4. Evaluasi pada Tahap Implementasi

Evaluasi pada tahap implementasi adalah evaluasi akhir pada film Pembelajaran IPA Kelas 5 SD. Evaluasi pada tahap implementasi dilakukan terhdap dengan melakukan uji pretest yang dilakukan sebelum film pembelajaran ditampilkan dan uji posttest dilakukan sesudah film pembelajaran ditampilkan. Hasil uji pretest dan postest mengacu pada kriteria ketuntasan minimal (KKM) di SD Negeri 7 Benoa.

\section{Teknik Pengumpulan Data}

Terdapat dua teknik pengumpulan data pada penelitian ini yaitu teknik instrumen angket dan tes hasil belajar. Adapun teknik pengumpulan data dalam penelitian ini dapat dilihat pada Tabel 1.

\section{Tabel 1. Teknik Pengumpulan Data}

\begin{tabular}{|c|c|c|}
\hline No. & $\begin{array}{c}\text { Teknik } \\
\text { Pengumpulan } \\
\text { Data }\end{array}$ & $\begin{array}{l}\text { Data yang } \\
\text { Dikumpulkan }\end{array}$ \\
\hline 1 & Angket & 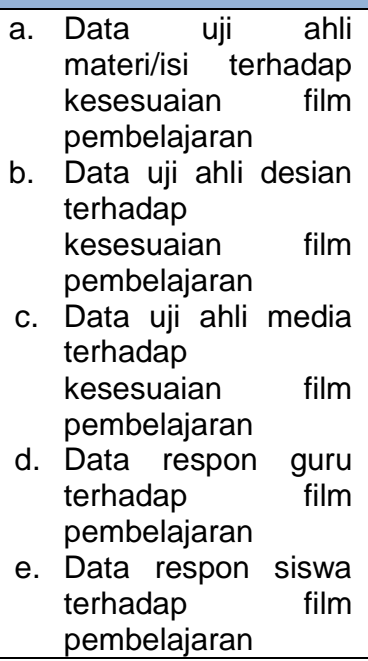 \\
\hline 2. & Tes hasil belajar & $\begin{array}{l}\text { a. Data hasil prestest } \\
\text { siswa } \\
\text { b. Data hasil posttest } \\
\text { siswa }\end{array}$ \\
\hline
\end{tabular}

\section{Uji Coba Instrumen Hasil Belajar}

a. Uji Validitas Instrumen Tes Hasil Belajar

Pada penelitian ini, validitas isi instrumen penelitian tes hasil belajar siswa dilakukan dengan menggunakan pertimbangan para ahli, yaitu satu orang dosen selain dosen pembimbing dan satu guru mata pelajaran. 
Hasil penilaian pakar terhadap validitas isi umumnya bersifat kualitatif. Salah satu teknik pengujian validitas isi yang lebih kuantitatif yaitu Formula Gregory. Pertimbangan ahli isi tersebut dianggap representatif sebagai dasar untuk memutuskan bahwa angket telah memenuhi syarat validitas isi.

b. Uji Validitas Butir Tes Hasil Belajar

Suatu item dikatakan valid apabila mempunyai dukungan yang benar terhadap skor total, atau dengan kata lain, sebuah item mempunyai kesejajaran dengan skor total. Kesejajaran antara validitas item dengan skor total dapat diartikan sebagai korelasi. Sehingga untuk mengetahui validitas item digunakan rumus korelasi. Pengujian ini dilakukan dengan cara membandingkan $r_{p b i s}$ hitung dengan $r_{p b i s}$ Tabel dalam taraf signifikan $5 \%$.

c. Uji Reliabilitas

Pengujian reliabilitas yang paling banyak digunakan dan sering ditemui dalam proses penelitian evaluasi adalah Kuder Recardson (K-R). Ada dua macam formula Kuder Ricardson, yaitu $\mathrm{KR}_{20}$ dan $\mathrm{KR}_{21}$. KR-20 dipakai apabila item tes menggunakan dua pilihan jawaban misalnya betul dan salah (B-S). Sedangkan $\mathrm{KR}_{21}$ digunakan untuk tes item yang dubuat sistematikanya menggunakan pilihan ganda misalnya pilihan ganda empat jawabannya, tiga jawaban dan sebagaimana. Pengujian reliabilitas ada penelitian ini menggunakan formula $\mathrm{KR}_{20}$. Alasan penggunaan rumus $K R_{20}$ pada tes ini karena item tes menggunakandua pilihan jawaban yaitu 0 dan 1 .

\section{Validasi Film}

a. Validasi Ahli Isi

Validasi isi bertujuan untuk memvalidasi materi pembelajaran yang terkandung di dalam film apakah sudah sesuai dengan konsep pengetahuan atau indikator yang ingin dicapai.

Dalam penelitian pengembangan ini untuk validasi ahli isi akan dilakukan oleh 2 ahli yaitu guru mata pelajaran IPA di SD No. 7 Benoa dan dosen jurusan Pendidikan Biologi Undiksha. Validasi isi film dilakukan menggunakan angket. Untuk melihat kriteria atau tingkat pencapaian pengembangan film, persentase yang telah diperoleh kemudian ditransformasikan ke dalam kalimat yang bersifat kualitatif

b. Validasi Ahli Desain

Validasi desain bertujuan untuk memvalidasi desian pembelajaran dari film pembelajaran IPA.

Pada tahap ini akan melibatkan 2 orang yang memiliki keahlian dalam bidang desian pembelajaran dengan spesifikasi minimal pendidikan S2 di Universitas Pendidikan Ganesha. Untuk validasi desain pembelajaran dilakukan dengan menggunakan angket. Untuk melihat kriteria atau tingkat pencapaian pengembangan film, persentase yang telah diperoleh kemudian ditransformasikan ke dalam kalimat yang bersifat kualitatif.

c. Validasi Ahli Media

Validasi media bertujuan untuk memvalidasi teknik-teknik penyampaian materi pembelajaran melalui editing film. Pada tahap ini akan melibatkan 2 orang yang memiliki keahlian dalam bidang film dengan spesifikasi minimal pendidikan S2 di Universitas Pendidikan Ganesha. Untuk validasi desain pembelajaran dilakukan dengan menggunakan angket. Untuk melihat kriteria atau tingkat pencapaian pengembangan film, persentase yang telah diperoleh kemudian ditransformasikan ke dalam kalimat yang bersifat kualitatif.

\section{HASIL DAN PEMBAHASAN}

\section{A. Hasil Penelitian}

Pengembangan Film Pembelajaran IImu Pengetahuan Alam untuk Kelas 5 Sekolah Dasar Negeri 7 Benoa menggunakan metode penelitian Research and Development $(R \& D)$ dengan model pengembangan ADDIE. Melalui tahapan pengembangan ADDIE telah dihasilkan sebuah film pembelajaran yang diharapkan dapat digunakan sebagai sumber dan media belajar siswa di sekolah dalam kegiatan pembelajaran IPA. Adapun hasil pengembangan Film Pembelajaran IImu Pengetahuan Alam kelas 5 dapat dilihat pada Gambar 2. 


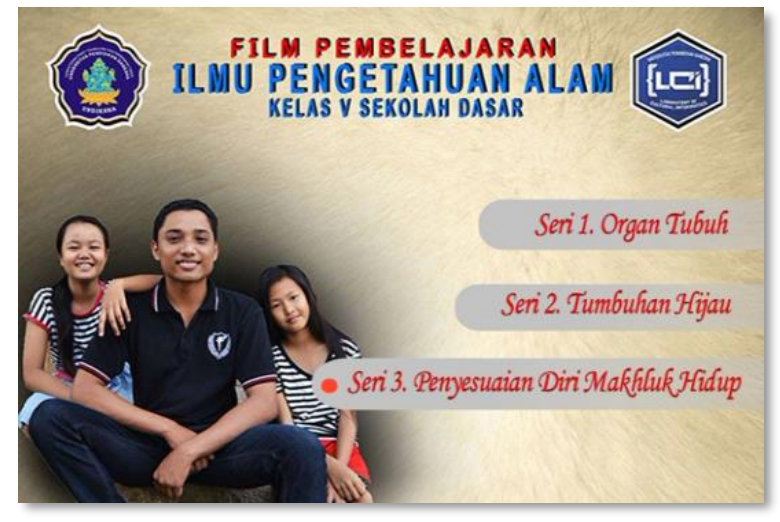

Gambar 2. Hasil Pengembangan Film Pembelajaran IPA Kelas 5

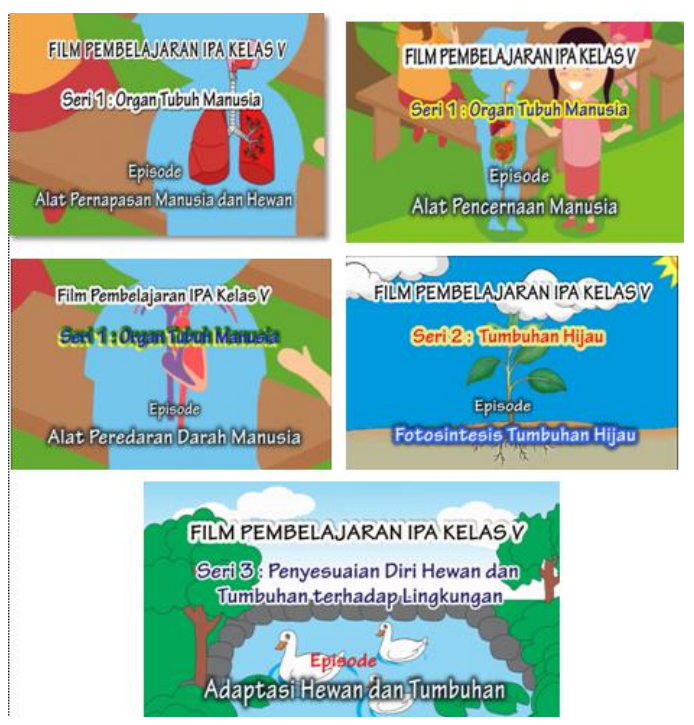

Gambar 3. Hasil Pengembangan Film Pembelajaran Ilmu Pengetahuan Alam Kelas 5 Setiap Episode

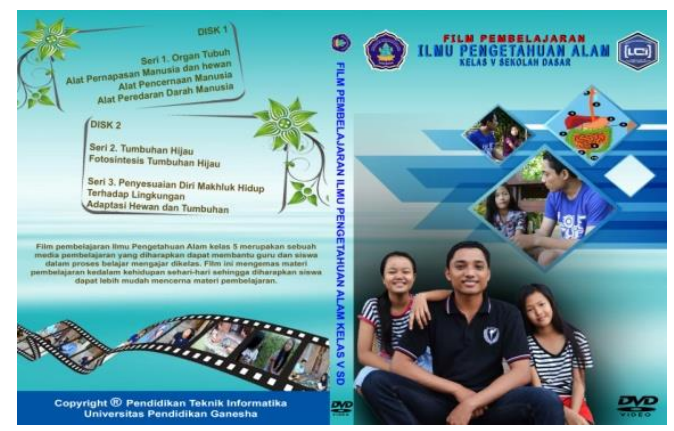

Gambar 4. Desain Cover Film Pembelajaran IImu Pengetahuan Alam Kelas 5 Setiap Episode

Film pembelajaran bisa digunakan sebagai sumber dan media belajar disekolah tentunya film pembelajaran tersebut harus dinyatakan valid, untuk itu film pembelajaran harus mengalami proses validasi uji ahli terlebih dahulu. Dalam pengembangannya film ini sudah mengalami pengujian dari para ahli. Pengujian dilakukan oleh 2 penguji ahli isi, 2 penguji ahli desian dan 2 penguji ahli media. Selain pengujian dari ahli isi, ahli desain dan ahli media juga dilakukan pengujian individu, kelompok kecil dan pengujian lapangan dengan memberikan pretest dan posttest. Sedangkan untuk mengetahui respon guru dan siswa terhadap film pembelajaran dilakukan pengujian respon kepada guru mata pelajaran IPA dan siswa siswa kelas 5 di SD No. 7 Benoa. Adapun hasil pengujian yang dimaksud adalah sebagai berikut.

a. Uji Ahli Isi

Uji ahli isi dilakukan pada seluruh bagian materi dari film pembelajaran yang dikembangkan. Pada uji ahli isi, pengujian dilakukan oleh Bapak Dr. Wayan Sukra Warpala, M.Sc. yang merupakan dosen di jurusan Pendidikan Biologi Undiksha dan lbu $\mathrm{Ni}$ Putu Suartini,S.Pd.SD yang merupakan guru mata pelajaran IPA di SD No. 7 Benoa. Masing-masing ahli isi menguji film pembelajaran sebanyak dua kali.

Dr. Wayan Sukra Warpala, M.Sc., pertama kali menguji film pembelajaran IPA pada tanggal 6 Februari 2017 dan uji tahap kedua pada tanggal 13 Februari 2017. Sedangkan ibu Ni Putu Suartini, S.Pd.SD., pertama kali menguji film pembelajaran IPA kelas 5 pada tanggal 27 Februari 2017 dan uji yang kedua pada tanggal 28 Februari 2017. Dari pengujian yang dilakukan oleh dua ahli isi tersebutkan didapatkan hasil seperti pada Tabel 2.

Tabel 2. Tingkat Pencapaian Film Berdasarkan Seluruh Hasil Uji Ahli Isi

\begin{tabular}{|c|c|c|c|c|c|}
\hline \multirow[b]{2}{*}{ No } & \multirow[b]{2}{*}{ Ahli Isi } & \multicolumn{4}{|c|}{ Shor Perolehan Tiap Indikator Penilaian } \\
\hline & & $\begin{array}{c}\text { Kelayakan } \\
\text { Isi }\end{array}$ & Kebahasaan & $\begin{array}{c}\text { Penyajian } \\
\text { Materi }\end{array}$ & $\begin{array}{l}\text { Kegrafikan } \\
\text { (ampilan) }\end{array}$ \\
\hline 1 & $\begin{array}{l}\text { Bapak Dr. } \\
\text { Wayan Sukra } \\
\text { Wrarpala, M.Sc. }\end{array}$ & 20 & 14 & 17 & 28 \\
\hline 2 & $\begin{array}{l}\text { Ni Putw } \\
\text { Suartini. } \\
\text { SPd.SD. }\end{array}$ & 18 & 14 & 19 & 18 \\
\hline \multirow{2}{*}{\multicolumn{2}{|c|}{$\begin{array}{l}\text { Jumlah Skor Perolehan } \\
\text { Skor Maksimal }\end{array}$}} & 38 & 28 & 36 & 46 \\
\hline & & 40 & 30 & 40 & 50 \\
\hline \multicolumn{2}{|c|}{$\begin{array}{l}\text { Persentase Tiap } \\
\text { Indikator }\end{array}$} & $95,00 \%$ & $93,33 \%$ & $90,00 \%$ & $92,00 \%$ \\
\hline \multicolumn{2}{|c|}{ Kriteria Tiap Indikator } & $\begin{array}{l}\text { Sangat } \\
\text { Bail: }\end{array}$ & Sangat Baik & $\begin{array}{l}\text { Sangat } \\
\text { Baik }\end{array}$ & $\begin{array}{l}\text { Sangat } \\
\text { Bail: }\end{array}$ \\
\hline \multicolumn{2}{|c|}{ Total Skor Perolehan } & \multicolumn{3}{|c|}{148} & \\
\hline \multicolumn{2}{|c|}{ Total Skor Maksima1 } & \multicolumn{3}{|c|}{160} & \\
\hline \multicolumn{2}{|c|}{$\begin{array}{l}\text { Persentase Total } \\
\text { Penilaian }\end{array}$} & \multicolumn{3}{|c|}{$92,50 \%$} & \\
\hline \multicolumn{2}{|c|}{ Kriteria } & \multicolumn{3}{|c|}{ Sangat Baik } & \\
\hline
\end{tabular}


b. Uji ahli Desain

Uji ahli desain dilakukan untuk menguji kesesuaian antara rancangan pembuatan film dengan hasil pengembangan film pembelajaran. Pada uji ahli desain, pengujian dilakukan oleh 2 ahli, yaitu Ibu Dr. Ketut Agustini, S.Si.,M.Si. yang merupakan dosen di jurusan S1 Pendidikan Teknik Informatika dan dosen di S2 Teknologi Pembelajaran, Undiksha dan Bapak Adrianus I Wayan llia Yuda Sukmana,S.Kom.,M.Pd. yang merupakan dosen di jurusan Teknologi Pendidikan Undiksha Singaraja.

Ibu Dr. Ketut Agustini, S.Si.,M.Si. menguji film pembelajaran IPA Kelas 5 pada tanggal 22 Februari 2017. Bapak Adrianus I Wayan llia Yuda Sukmana,S.Kom., M.Pd. menguji film pembelajaran IPA kelas 5 pertama kali pada tanggal 23 Februari 2017 dan uji yang kedua pada tanggal 24 Februari.

Dari pengujian yang dilakukan oleh dua ahli desain tersebutkan didapatkan hasil seperti pada Tabel 3.

Tabel 3. Tingkat Pencapaian Film

Berdasarkan Hasil Uji Ahli Desain

\begin{tabular}{|c|c|c|c|c|}
\hline \multirow[b]{2}{*}{ No } & \multirow[b]{2}{*}{ Ahli Desain } & \multicolumn{3}{|c|}{ Skor Perolehan Tiap Indikator Penilaian } \\
\hline & & $\begin{array}{l}\text { Kesesuaian } \\
\text { tujuan } \\
\text { pembelajaran }\end{array}$ & $\begin{array}{c}\text { Efektifitas } \\
\text { film } \\
\text { pembelajaran }\end{array}$ & $\begin{array}{c}\text { Keseseuaian } \\
\text { evaluasi }\end{array}$ \\
\hline 1 & $\begin{array}{l}\text { Dr. Ketut } \\
\text { Agustini, } \\
\text { S.Si.,MSi. }\end{array}$ & 15 & 19 & 8 \\
\hline 2 & $\begin{array}{l}\text { Adrianus I } \\
\text { Wayan Ilia } \\
\text { Yuda Sukma,S. } \\
\text { Kom,. MPd. } \\
\end{array}$ & 14 & 20 & 9 \\
\hline & $\begin{array}{r}\text { Jumlah Skor } \\
\text { Perolehan }\end{array}$ & 29 & 39 & 17 \\
\hline & Skor Maksimal & 30 & 40 & 20 \\
\hline \multicolumn{2}{|r|}{$\begin{array}{r}\text { Persentase Tiap } \\
\text { Indika tor }\end{array}$} & $96.67 \%$ & $97.50 \%$ & $85.00 \%$ \\
\hline \multicolumn{2}{|r|}{$\begin{array}{r}\text { Kriteria Tiap } \\
\text { Indika tor }\end{array}$} & Sangat Baik & Sangat Baik & Baik \\
\hline \multicolumn{2}{|c|}{$\begin{array}{r}\text { Total Rerata Skor } \\
\text { Perolehan } \\
\end{array}$} & \multicolumn{3}{|c|}{85} \\
\hline \multicolumn{2}{|c|}{ Total Skor Maksimal } & \multicolumn{3}{|c|}{90} \\
\hline \multicolumn{2}{|c|}{$\begin{array}{r}\text { PersentaseTota1 } \\
\text { Penilaian } \\
\end{array}$} & \multicolumn{3}{|c|}{$94,44 \%$} \\
\hline & Kriteria & \multicolumn{3}{|c|}{ Sangat Baik } \\
\hline
\end{tabular}

\section{c. Uji Ahli Media}

Uji ahli media dilakukan untuk menguji kesesuaian antara rancangan pembuatan film dengan hasil pengembangan film pembelajaran. Pada uji ahli media, pengujian dilakukan oleh 2 ahli, yaitu Bapak I Nyoman Rediasa,S.Sn.,M.Si. yang merupakan dosen di jurusan Seni Rupa Undiksha dan Bapak Adrianus I Wayan Ilia Yuda Sukmana, S.Kom.,M.Pd yang merupakan dosen di jurusan Teknologi Pendidian Undiksha Singaraja.
Dari pengujian yang dilakukan oleh dua ahli desain tersebutkan didapatkan hasil seperti pada Tabel 4.

Tabel 4. Tingkat Pencapaian Film Berdasarkan Seluruh Hasil Uji Ahli Media

\begin{tabular}{|c|c|c|c|c|}
\hline \multirow[t]{2}{*}{ No } & \multirow[t]{2}{*}{ Ahli Media } & \multicolumn{3}{|c|}{$\begin{array}{c}\text { Skor Per olehan Tiap Indikator } \\
\text { Penilaian }\end{array}$} \\
\hline & & Penggunaan & Film & Visual teks \\
\hline 1 & $\begin{array}{l}\text { I Nyoman Rediasa, } \\
\text { S.Sn., MSi. }\end{array}$ & 15 & 27 & 19 \\
\hline 2 & $\begin{array}{l}\text { Adrianus I Wayan Ilia } \\
\text { Yuda Sukmana, } \\
\text { S.Kom., MPd. }\end{array}$ & 15 & 26 & 20 \\
\hline & Jumlah Skor Perolehan & 30 & 53 & 39 \\
\hline & Rerata Skor Perolehan & 15 & 26,5 & 19,5 \\
\hline & Skor Maksimal & 15 & 30 & 20 \\
\hline & Persentase Tiap Indikator & 100,00 & 88,33 & 97,50 \\
\hline & Kriteria Tiap Indikator & Sangat Baik & Baik & Sangat Baik \\
\hline & tal Rerata Skor Perolehan & \multicolumn{3}{|c|}{61} \\
\hline & Total Skor Maksimal & \multicolumn{3}{|c|}{65} \\
\hline & Persentase Tota1 Penilaian & \multicolumn{3}{|c|}{93,85} \\
\hline & Kriteria & \multicolumn{3}{|c|}{ Sangat Baik } \\
\hline
\end{tabular}

\section{d. Uji Individu}

Uji individu dilakukan pada tanggal 28 Februari 2017. Uji individu melibatkan 3 orang siswa kelas 5 di SD No. 7 Benoa yang terdiri dari siswa yang memiliki prestasi belajar tinggi, sedang dan rendah. Hasil yang didapatkan siswa kemudian dibandingan dengan KKM yang diterapkan untuk mata pelajaran IPA kelas 5. KKM yang harus dipenuhi oleh siswa untuk mata pelajaran IPA adalah 77 .

Hasil yang diperoleh dalam uji individu ini adalah hasil pratest menunjukan bahwa rata-rata yang didapatkan 3 siswa adalah 70,00 dangan nilai ketiga siswa masih dibawah KKM dan masuk dalam katagori belum tuntas, sedangan untuk hasil posttest rata-rata yang didapatkan siswa meningkat menjadi 90,00, dimana nilai yang didapatkan ketiga siswa sudah diatas KKM dengan katagori tuntas. Untuk lebih jelasnya, tingkat pencapaian film berdasarkan hasil uji individu disajikan dalam bentuk grafik pada Gambar 3.

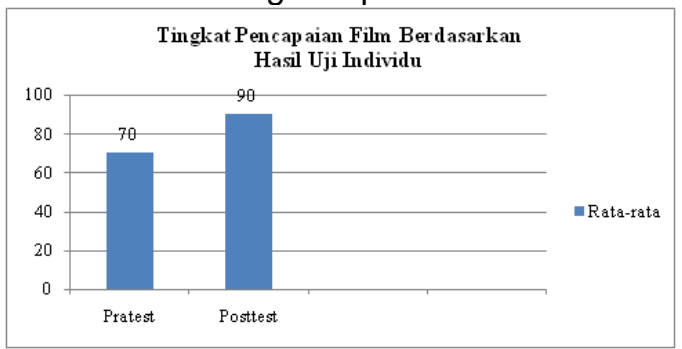

Gambar 3. Tingkat Pencapaian Film Berdasarkan Hasil Uji Individu 
Uji kelompok kecil dilakukan pada tanggal 28 Februari 2017 yang melibatkan 12 orang siswa kelas 5 di SD No. 7 Benoa yang terdiri dari 4 siswa yang memiliki prestasi belajar tinggi, 4 siswa yang memiliki prestasi belajar sedang dan 4 siswa yang memiliki prestasi belajar rendah. Hasil yang didapatkan siswa kemudian dibandingan dengan KKM yang diterapkan untuk mata pelajaran IPA kelas 5. KKM yang harus dipenuhi oleh siswa untuk mata pelajaran IPA adalah 77 .

Hasil yang diperoleh dalam uji kelompok kecil ini adalah hasil pratest menunjukan bahwa rata-rata yang didapatkan siswa adalah 75,00 dangan sebanyak 5 siswa mendapatkan nilai masih dibawah KKM dengan katagori belum tuntas dan 7 siswa yang mendapatkan nilai diatas KKM dengan katagori tuntas, sedangan untuk hasil posttest rata-rata yang didapatkan siswa meningkat menjadi 89,17, dimana nilai yang didapatkan semua siswa sudah diatas KKM dengan katagori tuntas. Untuk lebih jelasnya, tingkat pencapaian film berdasarkan hasil uji kelempok kecil disajikan dalam bentuk grafik pada Gambar 4.

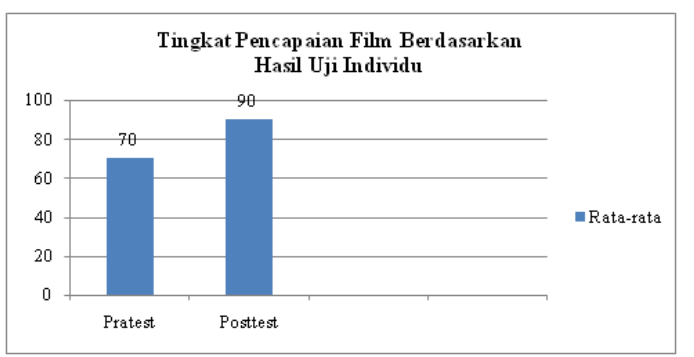

Gambar 4. Tingkat Pencapaian Film Berdasarkan Hasil Uji Kelompok Kecil

\section{f. Uji Lapangan}

Uji lapangan dilakukan pada tanggal 28 Februari 2017 melibatkan semua siswa kelas 5 di SD No. 7 Benoa yaitu sebanyak 35 siswa. Pada tahap ini siswa diberikan pratest, yaitu evaluasi yang diberikan sebelum film Pembelajaran IPA diputar untuk mengetahui pengetahuan dasar siswa dan posttest, yaitu evaluasi yang dilakukan setelah film diputar untuk mengetahui tingkat pemahaman siswa terhadap pelajaran IPA dengan menggunakan media film pembelajaran IPA. Hasil yang didapatkan siswa kemudian dibandingan dengan KKM yang diterapkan untuk mata pelajaran IPA kelas 5. KKM yang harus dipenuhi oleh siswa untuk mata pelajaran IPA adalah 77 .
Hasil yang diperoleh dalam uji lapangan ini adalah hasil pratest menunjukan bahwa rata-rata yang didapatkan siswa adalah 68,57 dangan sebanyak 21 siswa mendapatkan nilai masih dibawah KKM dengan katagori belum tuntas dan 14 siswa yang mendapatkan nilai diatas KKM dengan katagori tuntas, sedangan untuk hasil posttest rata-rata yang didapatkan siswa meningkat menjadi 85,43 , dimana nilai yang didapatkan semua siswa sudah diatas KKM dengan katagori tuntas. Untuk lebih jelasnya, tingkat pencapaian film berdasarkan hasil uji lapangan disajikan dalam bentuk grafik pada Gambar 5 .

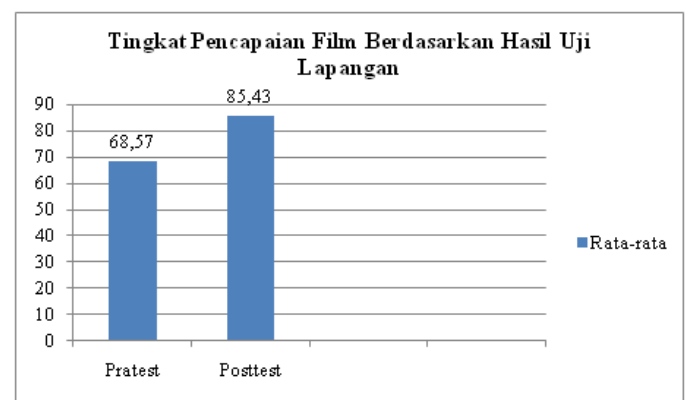

Gambar 5. Tingkat Pencapaian Film Berdasarkan Hasil Uji Lapangan

g. Uji Respon

1) Uji Respon Guru

Uji respon guru dilakukan pada hari rabu tanggal 1 Maret 2017, yang melibatkan guru mata pelajaran IPA kelas 5 yakni ibu Ni Putu Suartini, S.Pd.SD. Uji respon menggunakan angket untuk mengetahui tanggapan atau respon guru terhadap penggunaan film pembelajaran IPA kelas 5 .

Uji respon dilakukan terhadap guru mata pelajaran IPA kelas 5 Sekolah Dasar No. 7 Benoa yaitu ibu $\mathrm{Ni}$ Putu Suartini,S.Pd.SD. Dari hasil analisis uji respon diketahui bahwa rata-rata persentase dari 11 subyek (butir) penilaian yaitu $94,55 \%$ berdasarkan Tabel 3.2, film pembelajaran IPA kelas 5 masuk dalam kriteria sangat positif.

Berdasarkan tingkat pencapaian film di atas dapat diketahui bahwa secara umum film pembelajaran IPA kelas 5 masuk dalam kriteria sangat positif dengan persentase $94,55 \%$.

2) Uji Respon Siswa

Uji respon siswa dilakukan pada hari Rabu tanggal 1 Maret 2017 di 
ruang kelas 5 dengan melibatkan 41 siswa dikelas 5 . Kegiatan uji respon dimulai dari penyampaian tujuan dari uji respon kepada siswa Kelas 5 . Setelah penyampaian tujuan, selanjutnya adalah penayangan film pembelajaran pada LCD Proyektor dan menyimak film pembelajaran. Selesai menyimak film pembelajaran, penulis membagikan angket kepada siswa dan membimbing siswa untuk mengisi angket respon siswa sesuai dengan keadaan sebenarnya yang dialami oleh siswa.

Uji lapangan dilakukan terhadap 41 siswa kelas 5 Sekolah Dasar No. 7 Benoa. Dari hasil analisis uji respon diketahui bahwa rerata persentase dari 15 subyek (butir) penilaian yaitu 92,26\% film pembelajaran IPA kelas 5 masuk dalam kriteria sangat positif. Untuk mengetahui tingkat pencapaian film berdasarkan skala penilaian dilakukan perhitungan jumlah dan persentase jawaban siswa untuk setiap skala penilaian. Adapun tingkat pencapaian film berdasarkan hasil uji respon siswa untuk skala baik disajikan pada Tabel 5 .

Tabel 5. Tingkat Pencapaian Film Berdasarkan Hasil Uji Respon siswa

\begin{tabular}{|l|c|c|}
\hline \multicolumn{1}{|c|}{$\begin{array}{c}\text { Kriteria Tingkat } \\
\text { Pencapaian }\end{array}$} & Persentase (\%) & Jumlah Siswa \\
\hline Sangat Baik & $76 \%$ & 31 \\
\hline Baik & $24 \%$ & 10 \\
\hline Cukup Baik & $0 \%$ & 0 \\
\hline Tidak Baik & $0 \%$ & 0 \\
\hline Sangat Tidak Baik & $0 \%$ & 0 \\
\hline
\end{tabular}

Berdasarkan Tabel 6 . dapat diketahui bahwa dari 41 siswa, 31 siswa menyatakan film pembelajaran IPA kelas 5 masuk dalam kriteria sangat baik dan 10 siswa menyatakan film pembelajaran IPA kelas 5 masuk dalam kriteria baik. Untuk lebih jelasnya, tingkat pencapaian film berdasarkan hasil uji respon siswa disajikan dalam bentuk grafik pada Gambar 7.

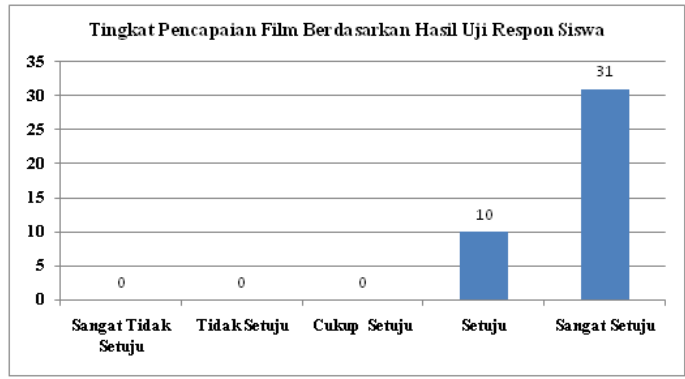

Gambar 6. Tingkat Pencapaian Film

Berdasarkan Hasil Uji Respon Siswa

\section{B. Pembahasan}

Berdasarkan analisis yang dilakukan terhadap uji ahli isi melalui instrumen berupa angket, adapun hasil yang diperoleh dari analisis data dua ahli isi adalah sebesar $92.50 \%$ dan dapat dikonversikan pada kualifikasi sangat baik. Hasil ini menunjukkan bahwa kesesuaian film Pembelajaran IPA Kelas 5 dengan aspek-aspek film sebagai media pembelajaran dilihat dari segi isi/materi yang disajikan dalam film pembelajaran sudah sesuai. Aspek-aspek film ini mencakup 4 aspek yaitu kelayakan isi, kebahasaan, penyajian materi, dan kegrafikan (tampilan), dimana pada aspek kelayakan isi, kedua ahli isi membarikan skor dengan persentase tertinggi dibandingkan dengan aspek aspek film lainnya yakni sebesar $95,00 \%$ dan dikonverikan dalam kategori sangat baik.

Film pembelajaan IPA selanjutnya diuji cobakan pada ahli desain. Uji ahli desain dilakukan terhadap uji ahli desain melalui instrumen berupa angket. Berdasarkan analisis data yang dilakukan terhadap uji ahli desain maka hasil yang diperoleh pada saat uji coba adalah sebesar $94,44 \%$ dan ketika dikonversikan pada tabel konversi, film pembelajaran IPA kelas 5 berada pada kualifikasi sangat baik dari segi desain pembelajaran.

Berdasarkan analisis yang dilakukan terhadap uji ahli media pembelajaran melalui instrumen berupa angket. Hasil yang diperoleh dari analisis data dua ahli media adalah sebesar $93,85 \%$ dan ketika dikonversikan pada tabel konversi berada pada kualifikasi sangat baik.

Berdasarkan nilai siswa pada uji individu, kelompok kecil, dan lapangan yang dilakukan menggunakan pratest dan posttest menyatakan bahwa film pembelajaran IPA kelas 5 rata-rata mengalami kenaikan yang cukup signifikan. Uji individu yang melibatkan 3 siswa menunjukan rata-rata hasil pretest yang 
diperoleh siswa masih dibawah KKM, sehingga ketiga siswa dinyatakan belum tuntas. Hasil berbeda ditunjukan dalam posttest yang dilakukan setelah siswa menonton film pembelajaran IPA kelas 5 . Rata-rata hasil postest menunjukkan kenaikan, dimana hasil postest yang diperoleh siswa sudah diatas KKM, sehingga ketiga siswa dinyatakan sudah tuntas. Hal ini berarti terdapat pengeruh kearah positif terhadap film yang dikembangkan, sehingga film pembelajaran IPA kelas 5 yang dikembangkan dapat dikatakan efektif untuk pembelajaran secara individu didalam kelas.

Analisis data uji kelompok kecil terhadap 12 siswa menunjukan rata-rata pretest lebih kecil daripada rata-rata posttest, dimana pada hasil pretest terdapat 7 siswa memperoleh nilai diatas KKM dan masuk dalam kategori tuntas dan 5 siswa memperoleh nilai dibawah KKM sehingga masuk dalam kategori belum tuntas. Sedangkan pada uji posttest ratarata diperoleh siswa mengalami kenaikan, dimana semua siswa yang menjadi subjek penelitian memperoleh nilai diatas KKM dengan kategori tuntas. Dengan demikian film pembelajaran yang dikembangkan memberikan pengaruh kearah positif, sehingga film pembelajaran IPA kelas 5 yang dikembangkan dapat dikatakan efektif untuk pembelajaran secara berkelompk.

Berdasarkan analisis data uji lapangan terhadap 21 siswa diperoleh hasil pretest dan posttest menunjukan bahwa rata-rata pretest lebih kecil daripada ratarata postest, dimana hasil pretest menunjukan bahwa 14 siswa memperoleh nilai diatas KKM dan masuk kategori tuntas dan 21 siswa memperoleh nilai dibawah KKM dan masuk dalam kategori belum tuntas. Pada uji postest rata-rata yang didapatkan mengalami peningkatan, dimana semua siswa memperoleh nilai diatas KKM dengan kategori tuntas. Hal ini menunjukan bahwa pengembangan film pembelajaran memberikan pengaruh kearah positif terhadap siswa, sehingga film pembelajaran IPA kelas 5 yang dikembangkan dapat dikatakan efektif untuk pembelajaran di dalam kelas.

Hasil uji ahli isi, desain, media, uji individu, kelompok kecil dan lapangan maka film pembelajaran IPA kelas 5 sudah efektif digunakan sebagai media pembelajaran dalam pembelajaran IPA di kelas 5 .
Berdasarkan hasil analisis data hasil penyebaran angket respon siswa terhadap penggunaan film pembelajaran IPA kelas 5, dapat diimplikasi bahwa terdapat respon yang sangat positif dari guru dan siswa setelah penggunaan film pembelajaran IPA kelas 5 di SD No. 7 Benoa. Data dari hasil respon guru mata pelajaran IPA terhadap film pembelajaran IPA kelas 5 yang dikumpulkan dengan butir pernyataan sebanyak 11 butir pernyataan. Berdasarkan analisis uji respon guru mata pelajaran IPA kelas 5 terhadap film pembelajaran IPA kelas 5 didapatkan fakta bahwa film pembelajaran mendapat respon yang positif dari guru mata pelajaran IPA. Berdasarkan analisis tersebut maka diperoleh hasil penyebaran angket respon guru terhadap penggunaan film pembelajaran IPA kelas 5 adalah sebesar 94,55 \% dengan kategori Sangat Positif.

Berdasarkan hasil pengolahan data yang dilakukan terhadap data hasil penyebaran angket respon siswa di kelas 5 setelah penerapan film pembelajaran dengan butir pernyataan sebanyak 15 butir pernyataan, diperoleh rata - rata hasil penyebaran angket respon siswa terhadap penggunaan film pembelajaran IPA adalah sebesar 92,26 \% dengan kategori Sangat positif.

\section{SIMPULAN}

Kesimpulan yang diperoleh dari hasil dan pembahasan penelitian pengembangan Film Pembelajaran IImu Pengetahuan Alam Kelas 5 SD No. 7 Benoa, antara lain adalah sebagai berikut.

1. Perancangan Film Pembelajaran IImu Pengetahun Alam Kelas 5 sudah berhasil dilaksanakan menggunakan model ADDIE.

2. Berdasarkan hasil implementasi Film Pembelajaran IImu Pengetahuan Alam Kelas 5 di SD No. 7 Benoa, menunjukan bahwa film pembelajaran IPA sudah berhasil diimplementasikan. Hal ini terlihat dari hasil uji individu, uji kelompok kecil dan uji lapangan yang dilakukan di SD No. 7 Benoa dimana pada pretest hasil yang didapatkan siswa masih ada dibawah KKM, namun pada hasil posttest hasil yang didapatkan siswa sudah diatas KKM.

3. Berdasarkan hasil perhitungan data hasil penyebaran angket respon guru dan siswa terhadap penggunaan film pembelajaran IPA kelas 5, dapat 
disimpulkan bahwa terdapat respon yang sangat positif dari guru dan siswa setelah penggunaan film pembelajaran IPA kelas 5 di SD No. 7 Benoa.

\section{DAFTAR PUSTAKA}

[1] Anisa, F.Nur. (2012). Hasil Belajar IPA .http://eprints.uny.ac.id/9893/2/bab\%202 \%20\%200810 8244039.pdf. (diakses pada tanggal 28 Januari 2016).

[2] Arsyad, A. (2006). Media pembelajaran. Jakarta: Raja Grafindo Persada

[3]Asyhar, R. (2012). Kreatif Mengembangkan Media Pembelajaran. Jakarta: Referensi.

[4] Kurniasih, Farida. (2013). Pengembangan Media Film Dokumenter Perusahaan Dagang Bagi Siswa SMK Kelas $X$ Akuntansi. Kajian Pendidikan Akuntansi Indonesia. 2(1): 21-36. Tersedia pada http://journal.student.uny.ac.id/jurnal/artikel/ $1547 / 44 / 246$ (diakses pada tanggal 28 Januari 2016).

[5] Marthaningtiyas, Andike, Harto Nuroso dan Joko Saefan. (2014). Efektivitas penggunaan Media Film Dokumenter Alam Semesta pada Pembelajaran IPA Materi Tata Surya Terhadap Hasil Belajar Siswa Kelas IX SMP Walisongo 1 Semarang. Prosiding Mathematic and Sciences Forum 2014. 2014

[6]Munadi, Yudhi. (2013). Media Pembelajaran Sebuah Pendekatan Baru. Jakarta : Refrensi (GP Press Group).

[7] Musfiqon. (2012). Pengembangan Media dan Sumber Pembelajaran. Jakarta: Prestasi Pustakaraya.

[8] Ozogul,G.(2010).Media Selection Models: Theory to Practice Model. Orizona State University Press.

[9]Pitaloka ,Whilis Putri. (2015). Pengembangan Media Film Pembelajaran Pendidikan Kewarganegaraan untuk Membentuk Karakter Pebelajar Kelas III Sekolah Dasar. Jurnal Pendidikan dan Pembelajaran. 4(11):1-15.Tersedia pada http://journal.uny.ac.id/index. php/jkpai/article/download/1185/996 (diakses pada tanggal 28 Januari 2016).

[10] Putri,Dityatama.(2013). Mengenal Genre Film dari isinyaa. Tersedia pada http://www.idseducation.com/articles/ mengenal-genre-film-dari-isinya/ (diakses tanggal 25 Februari 2016).

[11] Sanjaya, W. (2012). Media Komunikasi Pembelajaran Edisi Pertama. Jakarta: Kencana Prenada Media Group
[12] Suandinatha, Leo, Arthana, I K. R ,Wirawan, I M. A. (2015). Pengembangan Film Pembelajaran Sosiologi pada Kompetensi Mendeskripsikan Nilai dan Normal yang Berlaku dalam Masyarakat untuk Siswa Kelas $X$ di SMA Negeri 2 Singaraja. 4(1): 39-48. Tersedia pada http://pti.undiksha.ac.id/karmapati (diakses pada tanggal 12 Maret 2016).

[13] Sugiarsana, Juni, Darmawiguna, I G.M, Wirawan, I M. A . (2015). Pengembangan Film Pembelajaran Musim Penghujan pada Tema Peristiwa Alam untuk Siswa Kelas I Sekolah Dasar Laboratorium Undiksha Singaraja. 4(1): 28-38. Tersedia pada http://pti.undiksha.ac.id/karmapati (diakses pada 12 Maret 2016).

[14] Tegeh, I M., Jampel, I N. dan Pudjawan, K.(2014). Model Penelitian Pengembangan.Yogyakarta: Graha IImu. 